DOI: 10.17707/AgricultForest.63.1.22

\author{
Ammer MOHAMADI-NASAB \\ Alireza MOTALEBI-AZAR, SAm MOKTARZADEH ${ }^{I}$
}

\title{
THE EFFECT OF NAPHTHALENEACETIC ACID AND TWO CYTOKININS ON CALLUS AND SHOOT INDUCTION FROM HYPOCOTYLS THIN CELL LAYER EXPLANTS IN TOMATO (LYCOPERSICON ESCULENTUM MILL)
}

\begin{abstract}
SUMMARY
This research was carried out for evaluating the morphogenesis responses of hypocotyls thin cell layers (TCL) of Lycopersicon esculentum Mill with various concentrations of NAA- Naphthaleneacetic Acid (NAA) and two types of cytokinins. The TCLs (0.1-0.5 mm) of hypocotyls were cultured to MS medium, containing various concentrations of NAA $(0,0.3,0.5,1$ and $1.5 \mathrm{mg} / \mathrm{l})$ with 2 $\mathrm{mg} / \mathrm{l}$ of BAP and kin. The obtained callus was transferred to the regeneration medium. The results showed that callus induction occurred in the all cultures containing auxin and cytokinin. But, callus induction was not observed on the medium containing only BAP and kin. So, the presence of auxin is essential for callus induction. The percentage of root and shoots, callus weight and diameter with BAP significantly differ in various concentrations of NAA. BAP and NAA concentrations of $2 \mathrm{mg} / \mathrm{l}$ and $1.5 \mathrm{mg} / \mathrm{l}$ of had maximum effects on callus weight and diameter, respectively. However, the maximum shoots were observed with the concentration of $1 \mathrm{mg} / \mathrm{l}$ of NAA. Different concentrations of NAA with kin significantly affected callus weight and diameter root and shoots. The maximum callus weight and diameter as well as percentage of shoots happened in NAA concentrations of $2 \mathrm{mg} / \mathrm{l}$ and $1 \mathrm{mg} / \mathrm{l} \mathrm{kin}$, respectively. The maximum number of root was observed with the concentrations of $2 \mathrm{mg} / \mathrm{l} \mathrm{kin}$ and $0.3 \mathrm{mg} / \mathrm{l} \mathrm{NAA}$. The comparison between media containing BAP and kin showed that responses were better on the medium containing kin. Also, the amounts of roots, shoots and callus fresh weight were higher than those of BAP.
\end{abstract}

Keywords: hypocotyls, kin, Lycopersicon esculentum, shoots, thin cell layer culture

\section{INTRODUCTION}

Tomato (Lycopersicon esculentum Mill) is one of the most important species of Solanaceae and is cultivated in most parts of the world (Devi et al. 2008). Nowadays, in vitro techniques are important instruments for genetic

\footnotetext{
${ }^{1}$ Ammer Mohamadi -Nasab Faculty of Natural Science, University of Tabriz, Tabriz, IRAN Alireza Motalebi-Azar, Sam Moktarzadeh Department of horticultural Science, Faculty of Agriculture, Tabriz University, IRAN

Paper presented at the $7^{\text {th }}$ International Scientific Agricultural Symposium "AGROSYM 2016".

Notes: The authors declare that they have no conflicts of interest. Authorship Form signed online.
} 
achievements and it is required to increase the usage of their reform styles by optimizing effective factors in plant regeneration (Taji et al. 2002). In the tomato plant, regeneration has been reported from various explants such as shoot tips, cotyledon, stem, petiole, leaf, anther and inflorescence (Raziuddin et al. 2004; Costa et al. 2000). Tomato regeneration was observed with callus of leaf and cotyledon or directly through the thin layer cell (TCL) of inflorescences (Compton and Veilluxe, 1991). In vitro plant regeneration depends on many factors such as genotype, explant, chemical medium composition, growth regulators, intensity and quality of light and photoperiod and temperature (Reed, 1999). performed studies using four medium (N6, LS, B5 and MS) containing various hormone combinations showed that N6 medium resulted in the maximum number of shoots length, which probably can be attributed to the increase of the sulphate ammonium medium concentration, contributing to plant regeneration (Sheeja et al. 2004).

In addition to this type of explant (Chaudhry et al. 2004), medium composition and genotype (Ishag et al. 2009) and hormonal treatments (Philip et al. 1996) can affect plant regeneration in tomato. For the first time, thin cell layer (TCL) technology was originally used by Tran et al. (1974) for controlling the development of flowers, roots, shoots and somatic embryos in tobacco pedicel longitudinal TCLs. TCL culture techniques have mostly focused on size and origin of explant and, as units of proper development, they have been used for regeneration and morphogenesis (Teixeire et al. 2007). The advantage of TCL culture is that thin cells layers are similar in physiological terms and can begin all morphogenesis patterns; however, only one pattern can be observed in each treatment (Kiem and Tran, 1981). In addition, direct organogenesis in most plants like Begonia tuberous (Nhut et al. 2006), Lilium longiflorum (Nhut et al. 2001), Citrus (Carimi et al. 1999), Brassica napus (Ghnaya et al. 2008) and Digitaria sanguinalis (Le et al. 1997) has been reported using TCL. Since morphogenesis from hypocotyls TCL has not been reported in Lycopersicon esculentum Mill, in this research, morphogenesis (callus, shoot, root or somatic embryogenesis induction) containing various concentrations of NAA and two types of cytokinins (BAP and kin) were studied in the hypocotyl TCL of Lycopersicon esculentum Mill seeding.

\section{MATERIALS AND METHODS \\ Study placement and preparation of TCL explants}

This experiment was conducted at the tissue culture laboratory of the Department of Horticultural Sciences at the University of Tabriz, Iran. The seeds of tomato cultivar "Super Chief" were the surface sterilized using alcohol $70 \%$ (for $2 \mathrm{~min}$ ) followed by $2.5 \%$ Sodium hypochlorite for $15 \mathrm{~min}$. Then the seeds were rinsed with distilled water for five times. Aseptic seeds were cultured on hormone free MS medium (Murashige and Skoog, 1962). Hypocotyls were obtained from the 6 to 7 days old seedlings and were cut to 0.1 to $0.5 \mathrm{~mm}$ explants (TCL) using a scalpel under a laminar flow in an aseptic condition. 


\section{Plantation of explants and treatments}

TCL explants were transferred into the MS medium containing various concentrations of NAA $(0,0.3,0.5,1$ and $1.5 \mathrm{mg} / \mathrm{l})$ and two types of cytokinins, BAP and kin (each with $2 \mathrm{mg} / \mathrm{l}$ ) (both addition before autoclaving) for callus induction under darkness at $24 \pm 2^{\circ} \mathrm{C}$ for 4 weeks. The percentage of callus induction, callus diameter, callus color and number of the roots were recorded. After 4 weeks, the samples were transferred to the regeneration medium (MS free hormone) (Gubi et al. 2004).

\section{Statistical Analysis}

The experiment was conducted a factorial arrangement based on completely randomized design with three replications and 15 TCLs for each treatment combination. Data analysis was accomplished using the SPSS statistical software (Version 16.0) and the means were compared by Duncan New Multiple Range test at 5\% probability level.

\section{RESULTS AND DISCUSSION}

After 4 to 5 days, callus induction was observed from TCL explants and with all hormonal treatments, except in the medium containing only cytokinin. Figure $1 \mathrm{~A}$ and B shows TCL explants and creamy calli produced from them, respectively. Callus tissue was hard and dry, but not juicy. However, depending on the hormonal combination treatments the root and shoot signs were observed from the callus of different media. The high number of root was observed on the medium containing kin. In addition, the roots had significantly longitudinal growth (Figure 1, C). In contrast, with the media containing BAP, the root growth was stopped in the early stages (Figure 1, D).

The rooting response in this case is seemingly associated with the external NAA employed as well as with the internal auxin. Shoot induction was mainly occurred indirectly and from calli. The shoots contained several small trachoma, as one of the feature of Solanaceae (Figure 1, E). Afterwards, the roots were originated from the end of the produced shoots into the rooting medium; then the rooted shoots were transferred to the hormone free MS medium for the complete plant development (Figure 1, F).

Apart from the hormonal amount and combination, callus induction was occurred on all the media containing both hormones; auxin and cytokinin $(100 \%$ callus induction from explants). So, the analysis and mean comparisons were not performed for the percentage of callus induction. However, Chaudhry et al. (2004) reported 57 to $82 / 5 \%$ callus induction on the MS medium containing various hormonal combinations $(4 \mathrm{mg} / \mathrm{l} \mathrm{Kin,} 2 \mathrm{mg} / \mathrm{l} \mathrm{BAP,} 2 \mathrm{mg} / \mathrm{l} \mathrm{NAA}$ and 2 $\mathrm{mg} / \mathrm{l}$ IAA) using leaf and hypocotyl explants. On the other hand, callus induction was not observed on the medium containing only BAP or kin. This means that any type of auxin is an essential factor for callus induction.

In a similar research, it was determined that callus proliferation from the leaf and hypocotyl explants was greatly depended on the hormone composition of the medium (Sheeja et al. 2004). 

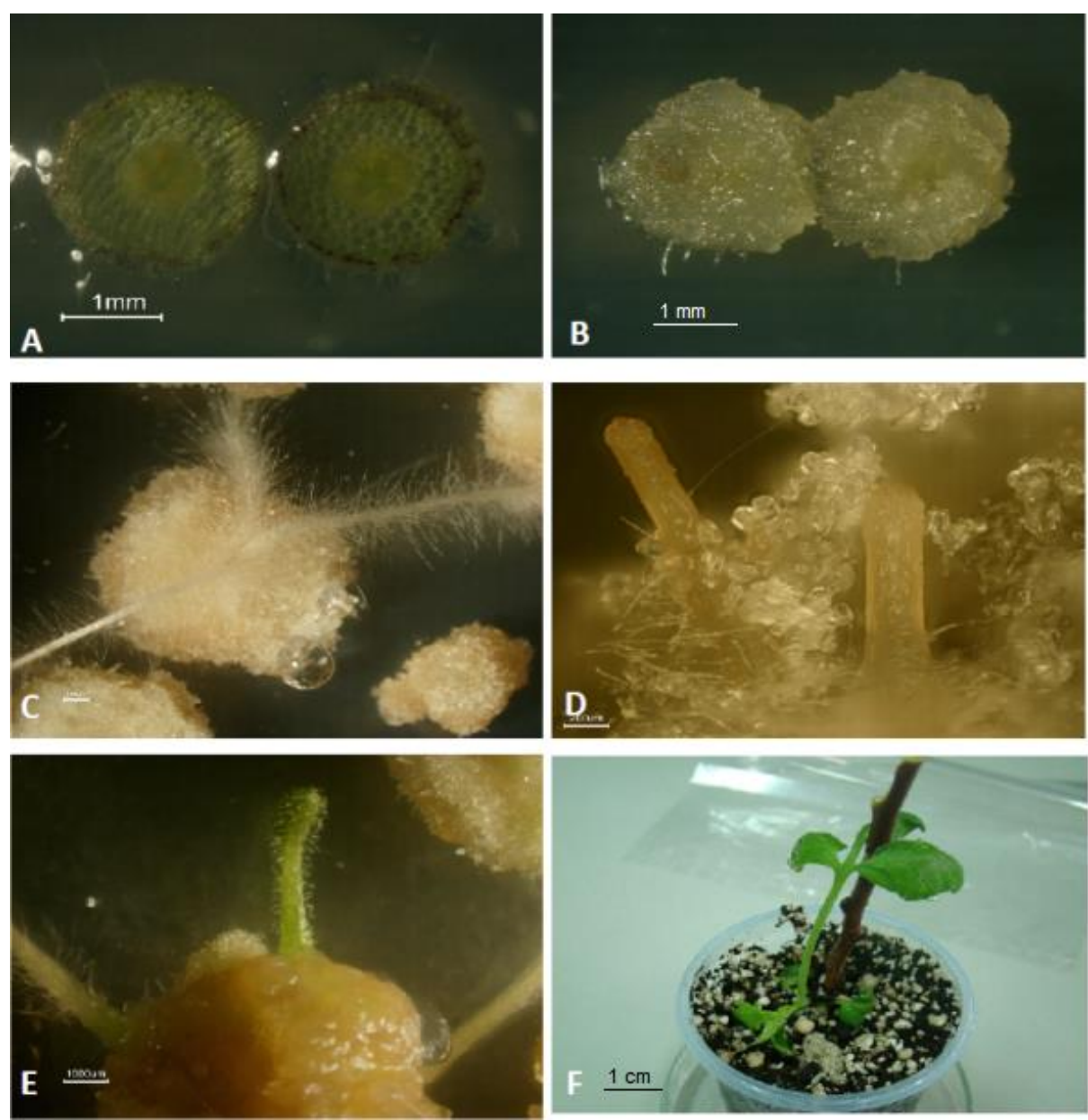

Figure 1. Thin Cell Layer (TCL) explants (A); Creamy callus produced from TCL (B); Root formation on the medium containing kin (C); Stopped root growth on the medium containing BAP (D). Shoot induction from callus with small trachoma (E). Plant regeneration on the hormone free MS medium (F).

A research conducted by Osman et al. (2010) verified that the callus induction potential from the hypocotyl explants of tomato was the highest on the MS medium containing one of the hormones of 2,4-D, TDZ and BAP with 0.5 $\mathrm{mg} / \mathrm{l} \mathrm{NAA}$ or a combination of $0.1 \mathrm{mg} / \mathrm{l} \mathrm{NAA}$ and $0.5 \mathrm{mg}$ BAP. However, the highest callus percentage was obtained with 2 to $3 \mathrm{mg} / \mathrm{l}$ NAA using cotyledon explants. In addition, regeneration through the callus from cotyledon was better than hypocotyl. Considering, TCLs are the explants of choice for the callus induction and its subsequent growth. By the way, the establishment and the capacity for the feasible and fast absorption of nutrients and growth regulators have been defined as the principle advantages for this explant type. One more advantage of TCL technique is the reliable determination of effective 
concentration of the external hormones with morphogenesis studies (Tran, 1981). In line, defined levels of external plant growth regulators along with internal phytohormons affect the morphogenesis potential of explant. Overlays, TCLs are undoubtedly the best explant types for the comprehensive studies of morphogenesis patterns. The results showed that kin was more effective than BAP regarding the studied traits. Callus diameter was influenced by various concentrations of NAA $(\mathrm{p}<0.01)$ on the medium containing either kin or BAP (Table 1). The effect was more pronounced with NAA concentration higher than $0.3 \mathrm{mg} / \mathrm{l}$. The maximum callus diameter of callus was observed in the media containing $1.5 \mathrm{mg} / \mathrm{l} \mathrm{NAA}$. The results showed that the increase in callus diameter was independent from the cytokinin type (Fig. 2A). Various concentrations of NAA significantly affected the callus fresh weight on the medium containing both BAP and kin $(\mathrm{p}<0.01)$ (Table 1). However, variation in of callus weight was dependent on the NAA concentration and cytokinin type. In the same way, on the media containing BAP, any increase in NAA level led to elevated calli fresh weight.

Table 1. Analysis of variance for callus diameter and weight, root and shoot induction percentage in response to NAA concentrations and two types of cytokines

\begin{tabular}{|c|c|c|c|c|c|}
\hline \multicolumn{7}{|c|}{ Mean Squares } \\
\hline $\begin{array}{c}\text { Source of } \\
\text { variations }\end{array}$ & df & $\begin{array}{c}\text { Callus } \\
\text { diameter }\end{array}$ & $\begin{array}{c}\text { Callus } \\
\text { Weight }\end{array}$ & Root (\%) & Shoot (\%) \\
\hline NAA & 4 & $2.66^{*}$ & $564.3^{* *}$ & $0.251^{* *}$ & $0.215^{*}$ \\
\hline Cytokinins & 1 & 0.95 & $256.1^{* *}$ & $0.122^{*}$ & $0.987^{* *}$ \\
\hline $\begin{array}{c}\text { NAA x } \\
\text { Cytokinins }\end{array}$ & 5 & $5.47^{* *}$ & $756.8^{* *}$ & $1.256^{* *}$ & $1.002^{* *}$ \\
\hline Error & 20 & 0.58 & 50.2 & 0.045 & 0.061 \\
\hline
\end{tabular}

The highest value for calli fresh weight was achieved using $1.5 \mathrm{mg} / \mathrm{l} \mathrm{NAA}$ and with the presence of BAP. No significant difference was observed among the NAA concentrations ranging from 0.3 to $1 \mathrm{mg} / \mathrm{l}$. However, there was a significant difference between these concentrations and $1.5 \mathrm{mg} / \mathrm{l} \mathrm{NAA}$ (Figure 2B). With media containing kin, callus fresh weight was increased using NAA ranging from 0.3 to $1 \mathrm{mg} / \mathrm{l}$, but it significantly decreased by $1.5 \mathrm{mg} / \mathrm{l}$ NAA (Figure 2B). As shown in Figure 2B, kin was more effective on callus fresh weight compared with BAP. Root initiation was more evident on the media containing kin and NAA when being compared with BAP and NAA. In addition, root growth was more intensified on media containing kin.

Beyond root initiation, the subsequent root growth was stopped with the media containing BAP. Root induction from callus was influenced by the different concentrations of NAA and cytokinin type $(\mathrm{p}<0.01)$ (Table 1). With media containing BAP, rooting percentage was declined with any increase in the concentrations of NAA. 

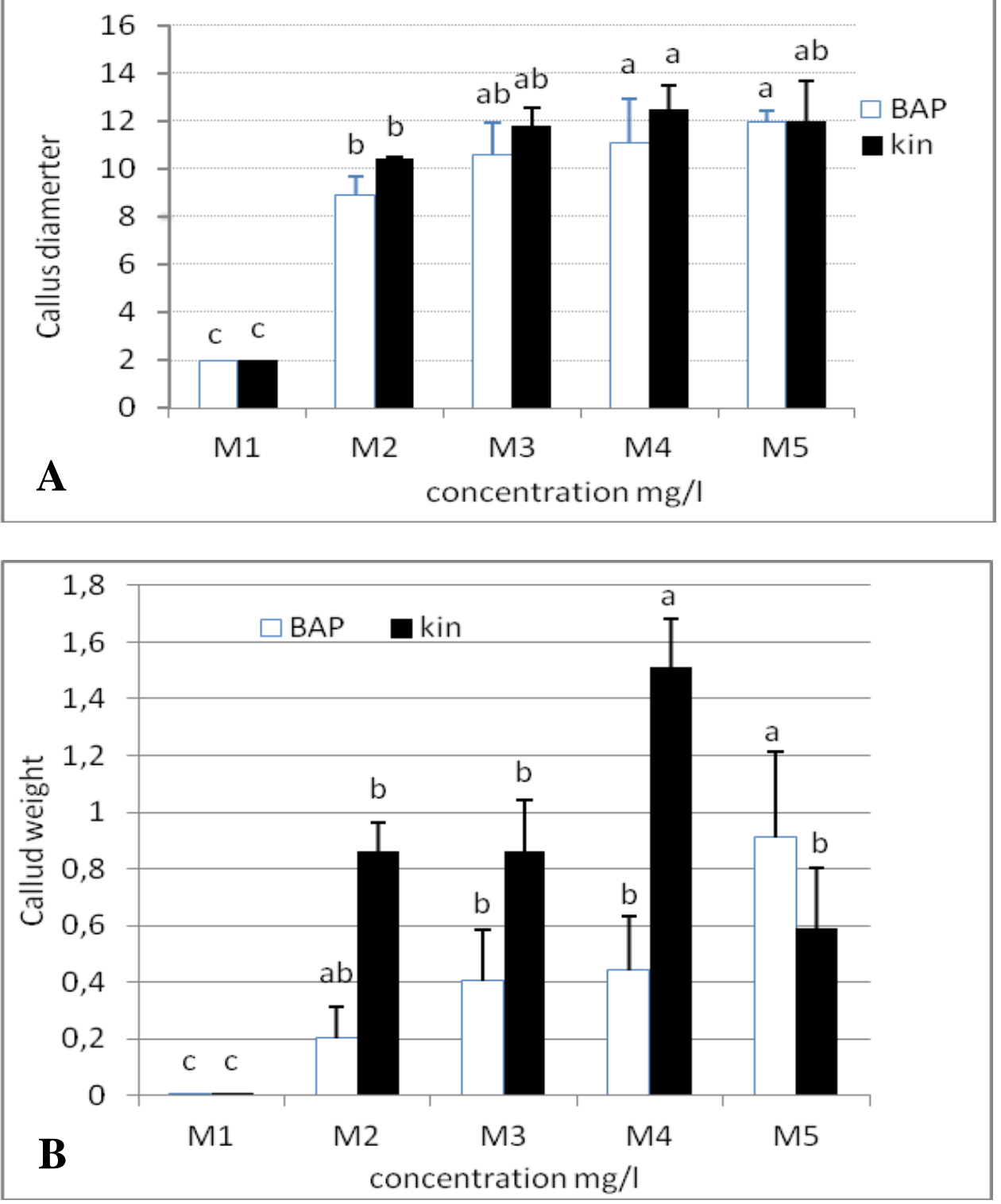

Figure 2. The average of callus diameter (A) and weight (B) in different concentration of NAA $(0.0 .3,0.5,1,1.5 \mathrm{mg} / \mathrm{l}$ show that by M1-M5) in presence of $2 \mathrm{mg} / \mathrm{l} \mathrm{BAP}$ or kin. Different letters show significant difference based on Duncan's multiple range test, $\mathrm{p}=0.05$.

The maximum number of roots was observed in the media enriched with 0.3 and $0.5 \mathrm{mg} / \mathrm{l} \mathrm{NAA}$ and the least data were occurred in the media containing 1 
and $1.5 \mathrm{mg} / \mathrm{L}$ NAA (Fig. 3). Also, in the media containing kin, the rooting percentage was decreased with any raise in the amount of NAA. The maximum of rooting percentage of roots was observed in $0.3 \mathrm{mg} / \mathrm{l} \mathrm{NAA}$ with significant difference from higher concentrations. The lowest data for this trait was observed in the concentration of $1.5 \mathrm{mg} / \mathrm{l}$ (Fig. 3). So, as routinely expected, the higher auxin levels were failed root induction. Fig. 3 shows that with the NAA presence, kin was more efficient than $\mathrm{BAP}$ considering rooting percentage.

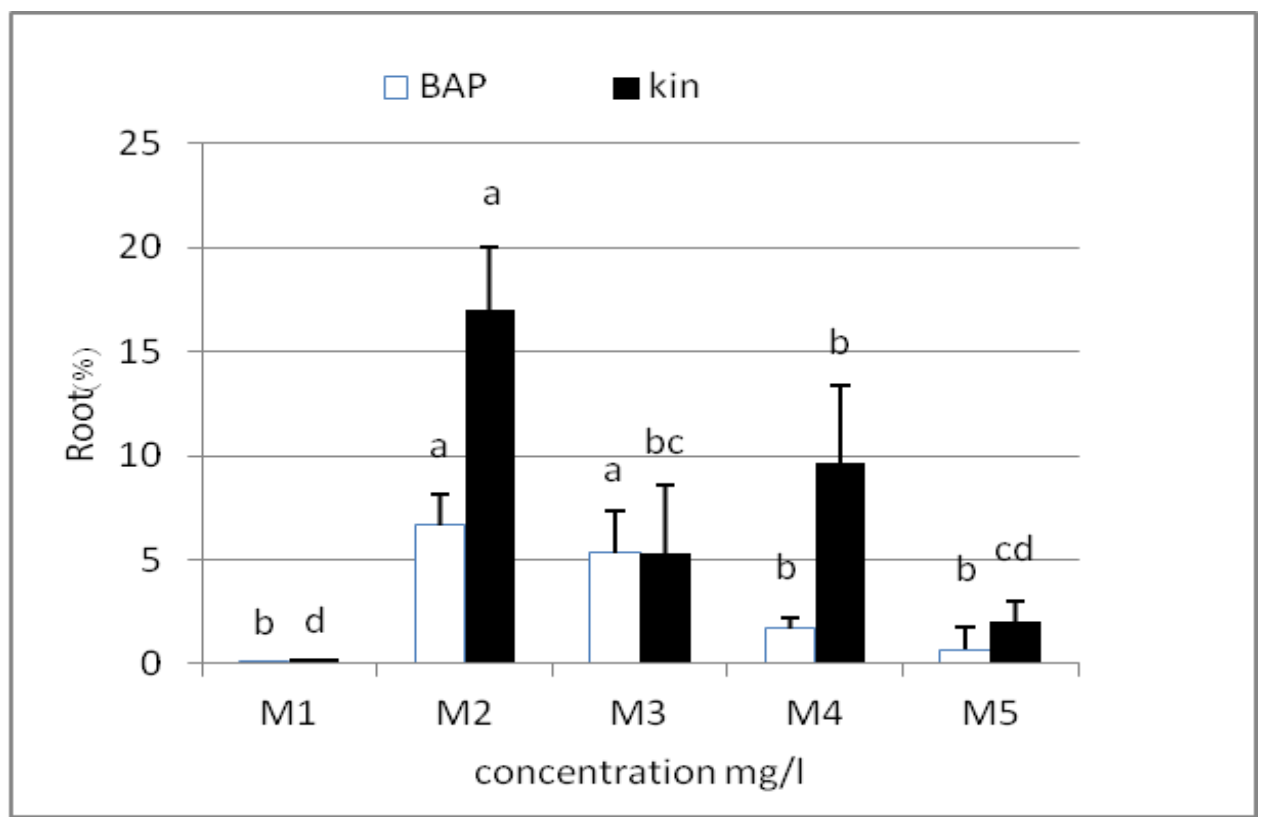

Figure 3. The average of root in different concentration of NAA (0. 0.3, $0.5,1,1.5 \mathrm{mg} / \mathrm{l}$ show that by M1-M5) in presence of $2 \mathrm{mg} / \mathrm{l} \mathrm{BAP}$ or kin. Different letters show significant difference based on Duncan's multiple range test, $\mathrm{p}=$ 0.05 .

There is strong evidence that kin progressively improved the rooting potential in alfalfa (Arcioni et al. 1990). Moreover, the rooting on the regeneration medium significantly was dependent on the various concentrations of NAA. Also, two cytokinin types held the same response. With both media containing BAP or kin, the increase in shoot induction was correlated with the increase in NAA concentration till $1 \mathrm{mg} / \mathrm{l}$. Any further increase in NAA levels led to the pronounced decrease in shoot induction potential. This indicates that for shoot induction and proliferation the participation of both hormones (auxin and cytokinin) is necessary, but their certain concentration needs special attention. Besides, as can be seen in Fig. 4, the medium containing kin had more percentage of shoots compared with media enriched with BAP in various concentrations of NAA. Also, shoots number was more on the medium containing kin rather than BAP. Several previous studies have notified that the 
type and amount of cytokinins are main factors affected shoot induction and subsequent growth (Abdellatef and Khalafallah, 2007). In tomato, Ishag et al. (2009) reported the shoot regeneration on the MS medium containing kin was more than the medium incorporated with BAP and 2ip. Also, with our study, it was determined that kin was more efficient than BAP in case for the shoots related traits and the shoots regeneration was also complete with the media containing kin. Furthermore, this study revealed that the combination of NAA with BAP and kin was not enough potentiate for the proliferation of tomato plant compared to the medium that only contains cytokinin. Similarly, Gulati and Jaiwal (1992) reported that NAA adding to the medium containing cytokinin did not improve the shoot multiplication.

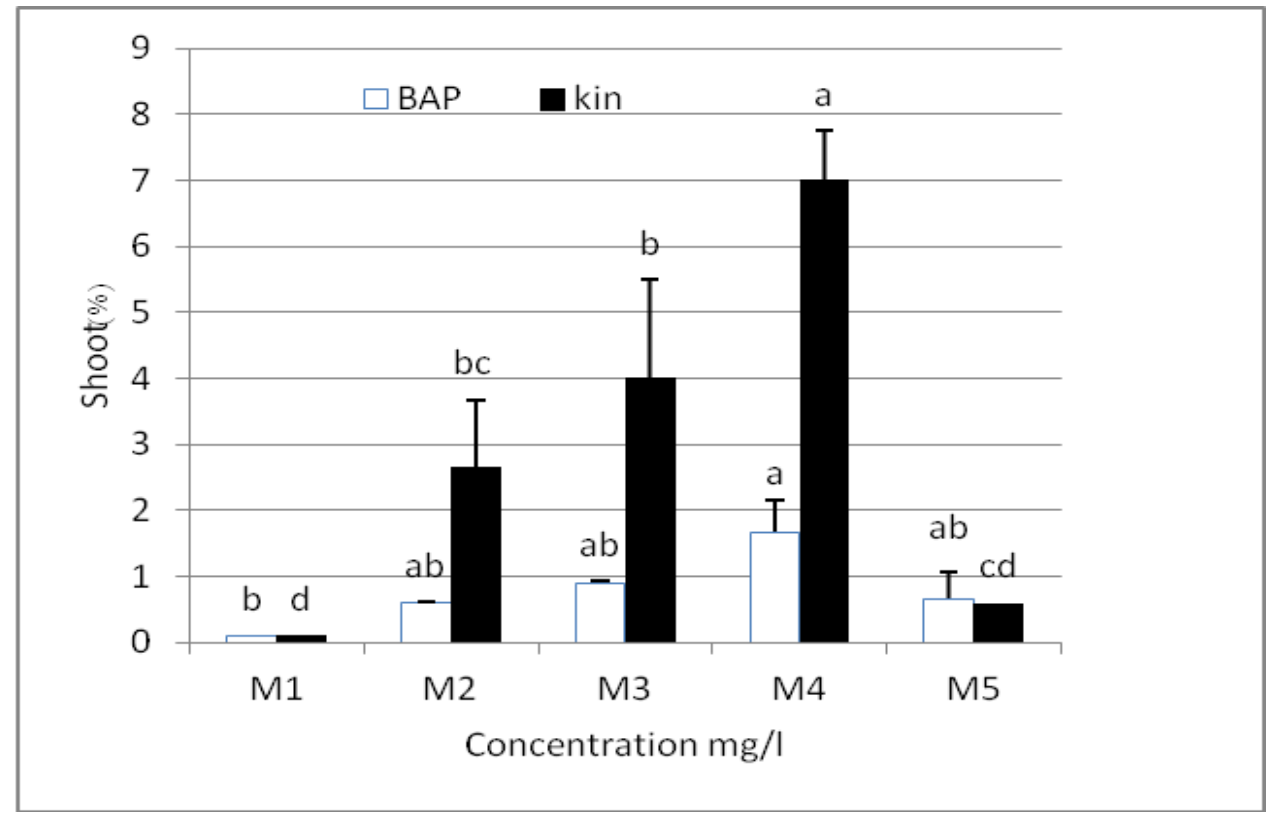

Figure 4. The average of shoot in different concentration of NAA (0. 0.3, $0.5,1,1.5 \mathrm{mg} / \mathrm{l}$ show that by M1-M5) in presence of $2 \mathrm{mg} / \mathrm{l} \mathrm{BAP}$ or kin. Different letters show significant difference based on Duncan's multiple range test, $\mathrm{p}=$ 0.05 .

\section{CONCLUSIONS}

Results of these experiments show the influence and importance of growth regulators on the callus diameter and weight as well as root and shoot induction from TCL explants of tomato. Although plants have endogenous growth hormones, they are sometimes required to be supplemented under in-vitro conditions to obtain optimal results. This is corroborated by the reports of Jozef et al. 2004, that the addition of growth regulators in media enhanced the number of shoots regenerated from tomato cotyledons and hypocotyls. The in-vitro morphogenic responses of $i n$-vitro cultured plant tissues are therefore affected by 
the different components of the culture media, especially by concentration of growth hormones. These responses are also dependent on cultivar and explants types. The addition of plant growth hormones to the shoot regeneration medium could therefore enhance shoot regeneration in this cultivar and explants.

\section{REFERENCES}

Abdellatef, E., and Khalafallah, M.M. 2007. Adventitious shoot formation and plant regeneration in medium staple cotton (Gossypium hirsitum L.) cultivar (Barac B67). International Journal of Agriculture and Biolbiology; 9, 913- 916.

Arcioni, S.F., Pezzoti, M., and Lupotto, E. 1990. Alfalfa, Lucern (Medicago spp). In: Biotecnology in Agriculture and forestry: Legumes and oilseed crops (Ed. Y.P. Bajaj). Spring Verlag, Berlin Germany. 1990. 197-241.

Beck, M.J., and Caponetti, J.D. 1983. The effect of kinetin and naphthaleneacetic acid on in vitro shoot multiplication and rooting in the fishtail fern. American Journal of Botany. 70, 1-7.

Carimi, F., Pasquale, F., and Crescimanno, D. 1999. Somatic embryogenesis and plant regeneration from pistil thin cell layers of citrus. Plant Cell Report. 18, 935-940.

Chaudhry, Z., Habib, D., Rashid, H., and Qureshi, S.A. 2004. Regeneration from various explant of in vitro seedling of Tomato (Lycopersicon esculentum L. c.v. Roma). Pakistan Journal of Biological Sciences. 7, 269-272.

Compton, M.E., and Veilluxe, R.E. 1991. Shoot, root and flower morphogenesis on tomato inflorescence explants. Plant Cell, Tissue and Organ Culture. 24, 223-231.

Costa, M.G.C., Nogueira, F., Figueira, M.L., Otoni, W.C., Brommonschenke, S.H., and Cecon, P.R. 2000. Influence of the antibiotic timentin on plant regeneration of tomato (Lycopersicon esculentum Mill.) cultivars. Plant Cell Reports. 19, 327-332.

Devi, M., Dhaliwal, M.S., Kaur, A., and Gosal, S.S. 2000. Effect of growth regulators on in vitro morphogenetic response of tomato. Indian Journal of Biotechnology. 7, 526- 530.

Ghnaya, B.A., Charles, G., and Branchard, M. 2008. Rapid shoot regeneration from thin cell layer explant excised from petioles in four cultivars of Brassica napus L. Plant Cell, Tissue and Organ Culture. 92, 25-30.

Gubi, J., Lajchova, Z., Farago, J., and Jurekova, Z. 2004. Effect of growth regulators on shoot induction and plant regeneration in tomato (Lycopersicon esculentum Mill.). Biologia, Bratislava. 59: 405-408.

Gulati, A., and Jaiwal, P.K. 1992. In vitro induction of multiple shoots and plant regeneration from shoots tip of mung bean (Vigna radiate (L.)). Plant Cell Tissue and Organ Culture. 29, 199-205.

Jozef, G., Zuzana, L., \& Zuzana, J. 2004. Effect of growth regulators on shoot induction and plant regeneration in tomato (Lycopersicum esculentum Mill.). Biologia Bratislava, 59(3), 405-408.

Ishag, S., Osman, M.G., and Khalafalla, M.M. 2009. Effects of growth regulators, explant and genotype on shoot regeneration in tomato (Lycopersicon esculentum c.v). Omdurman. Int. J. Sustain. Crop Prod. 4, 7-13.

Kiem, M., and Tran, T.V. 1981. Control of morphogenesis in in vitro Cultures. Ann. Rev. Plant Physiology. 32, 291-311.

Le, B.V., Thao, N.D., Gendy, C., Vidal, J., and Van, T.K. 1997. Somatic embryogenesis on Thin Cell Layers of a C4 species, Digitaria sanguinalis (L.) Scop. Plant Cell, Tissue and Organ Culture. 49:, 201-208.

Murashige, T, and Skoog F, 1962. A revised medium for rapid growth and bioassay with tobacco tissue cultures. Physiological Plant. 15: 473-497. 
Nhut, D.T., Bui, L., Tran, T.V.M, and Aswath, C.R. 2001. Thin cell layer cultures system in Lilium: Regeneration and transformation perspectives. In Vitro Cell. Dev. Biol. Plant. 37, 516-523.

Nhut, D.T, Phan, M.X., Hai, N.T., Son, P.D.T., Huyen, P.X., and Hang, N.T.T. 2006. Thin cell layer technology and bioreactor culture in rapid propagation of Begonia tuberous. Proceedings of International Workshop on Biotechnology in Agriculture. 127- 130.

Osman MG, Elsadig A, Elhadi B, Khalafalla MM. Callus formation and organogenesis of tomato (Lycopersicon esculentum Mill, C.V. Omdurman) induced by thidiazuron. African Journal of Biotechnology. 2010; 9: 4407-4413.

Philip ON, Sankaran K, Praveen KS. Regeneration of Tomato (Lycopersicon esculentum L.): Somatic embryogenesis and shoot organogenesis from hypocotyl explants induced with 6-Banzyl adenine. Int. J. Plant Sci. 1996; 157: 554-560.

Philip ON, Newman SK, Praveen K, Saxena A. Regeneration of Tomato (Lycopersicon esculentum Mill.): Somatic Embryogenesis and Shoot Organogenesis from hypocotyl explants induced with 6-Benzyladenine. Int. J. Plant Sci. 1996; 157: 554-560.

Raziuddin S, Salim HJ, Chaudhary T, Mohammad A. Hormonal effect on callus induction in Tomato. Sarhad J. Agric. 2004; 20: 223-225.

Reed BM. Design a micropropagation system: Workshop presentation from the 1998 SIVB Congr. On in vitro Biology. In Vitro Cell Dev. Biol. Plant. 1998; 35: 275 284.

Ruzic DJ, Vujovic VT. The effects of cytokinin types and their concentration on in vitro multiplication of sweet cherry cv. Lapins (Prunus avium L.). Hort. Sci. (Prague). 2008; 35: 12-21.

Sheeja TE, Asit B, Monda F, Rathore RKS. Efficient Plantlet Regeneration in Tomato (Lycopersicon esculentum Mill.). Plant Cell Tissue Organ Culture. 2004; 14: 4553.

Taji A, Kumar PP, Lakshmanan P. In Vitro Plant Breeding, Food Products Press, New York, 2002.

Teixeire DSAJ, Tran TVK, Biondi S, Nhut DT, Altamura MM. Thin cell layer: Developmental building block in ornamental biotechnology. Floriculture and Ornamental Biotechnology. 2007; 1: 1-13.

Tran TVK, Dien N, Chlyah, A. Regulation of organogenesis in small explant of superficial tissue of Nicotiana tabacum L. Planta. 1974; 119: 149-159.

Tran TVK. Control of morphogenesis by inherent and exogenously applied factors in thin cell layers. Int. Rev. Cytol. Suppl. 1981; 11: 75-194 